\title{
molecules
}

ISSN 1420-3049

www.mdpi.com/journal/molecules

Article

\section{Steroidal Saponins from the Roots and Rhizomes of Tupistra chinensis}

Yuze Li ${ }^{1, \dagger}$, Xin Wang ${ }^{2, \dagger}$, Hao He ${ }^{3}$, Dongdong Zhang ${ }^{1}$, Yi Jiang ${ }^{1}$, Xinjie Yang ${ }^{1}$, Fei Wang ${ }^{1}$, Zhishu Tang ${ }^{1}$, Xiaomei Song ${ }^{1, *}$ and Zhenggang Yue ${ }^{1, *}$

1 Shaanxi Collaborative Innovation Center of Chinese Medicinal Resource Industrialization, Shaanxi Province Key Laboratory of New Drugs and Chinese Medicine Foundation Research, Shaanxi Rheumatism and Tumor Center of TCM Engineering Technology Research, School of Pharmacy, Shaanxi University of Chinese Medicine, Xianyang 712046, China; E-Mails: lyz1990yeah@163.com (Y.L.); zhangnatprod@163.com (D.Z.); j9668216@126.com (Y.J.); xxx211xxx@126.com (X.Y.); wf88-88@163.com (F.W.); tzs6565@163.com (Z.T.)

2 The First Hospital of Xi'an, Xi'an 710002, China; E-Mail: wangxin.x@163.com

3 School of Pharmaceutical Sciences, Xi'an Medical University, Xi'an 710021, China; E-Mail: hehao313@163.com

$\dagger$ These authors contributed equally to this work.

* Authors to whom correspondence should be addressed; E-Mails: songxiaom@126.com (X.S.); liuxingjian1981@163.com (Z.Y.); Tel.: +86-136-3673-3632 (X.S.); +86-180-9208-6211 (Z.Y.).

Academic Editor: Derek J. McPhee

Received: 25 June 2015 / Accepted: 23 July 2015 / Published: 28 July 2015

\begin{abstract}
Two new furostanol saponins 1-2 and a new spirostanol saponin $\mathbf{3}$ were isolated together with two known furostanol saponins 4-5 from the roots and rhizomes of Tupistra chinensis. Their structures were characterized as $1 \beta, 2 \beta, 3 \beta, 4 \beta, 5 \beta, 26-$ hexahydroxyfurost-20(22), 25(27)-dien-5,26-O- $\beta$-D-glucopyranoside (1), 1 $\beta, 2 \beta, 3 \beta, 4 \beta, 5 \beta, 6 \beta, 7 \alpha, 23 \xi, 26$-nona-hydroxyfurost20(22),25(27)-dien-26-O- $\beta$-D-glucopyranoside (2), (20S,22R)-spirost-25 (27)-en-1 $\beta, 3 \beta, 5 \beta$ trihydroxy-1-O- $\beta$-D-xyloside (3), tupisteroide B (4) and $5 \beta$-furost- $\Delta^{25(27)}$-en- $1 \beta, 2 \beta, 3 \beta, 4 \beta, 5 \beta, 7 \alpha$, $22 \xi, 26$-octahydroxy-6-one-26-O- $\beta$-D-glucopyranoside (5), respectively, by extensive use of spectroscopic techniques and chemical evidence. Additionally, the in vitro cytotoxic activity of 1-4 was evaluated on human A549 and H1299 tumor cell lines, and compound $\mathbf{3}$ exhibited cytotoxicity against A549 cells ( $\mathrm{IC}_{50} 86.63 \pm 2.33 \mu \mathrm{mol} \cdot \mathrm{L}^{-1}$ ) and $\mathrm{H} 1299$ cells (IC50 $88.21 \pm$ $\left.1.34 \mu \mathrm{mol} \cdot \mathrm{L}^{-1}\right)$.
\end{abstract}


Keywords: Tupistra chinensis; steroidal saponins; structure identification; cytotoxic activity

\section{Introduction}

Tupistra chinensis Baker., a species in the Tupistra genus of the Liliaceae family, is used as an endemic herbal medicine, known as "Kai-Kou-Jian”, in the Qinba Mountains of Shaanxi Province in China [1]. The roots and rhizomes of $T$. chinensis are commonly used as folk medicine to treat throat irritation, rheumatic diseases and snake-bites [2,3]. Modern pharmacological experiments have showed that the extracts of this species possess significant antitumor activities [4,5], moreover, two main kinds of componentscardenolides and saponins-were isolated from $T$. chinensis [3,6,7]. As part of our research project to find more diverse bioactive leading compounds from the medicinal herbs of the Qinba Mountains [8-11], the chemical constituents and pharmacological studies of $T$. chinensis were investigated, and two new furostanol saponins, $1 \beta, 2 \beta, 3 \beta, 4 \beta, 5 \beta, 26$-hexahydroxyfurost-20(22),25(27)-dien-5,26-O- $\beta$-D-glucopyranoside (1), $1 \beta, 2 \beta, 3 \beta, 4 \beta, 5 \beta, 6 \beta, 7 \alpha, 23 \xi, 26$-nonahydroxyfurost-20(22),25(27)-dien-26- $O$ - $\beta$-D-glucopyranoside (2), and a new spirostanol saponin $(20 S, 22 R)$-spirost-25(27)-en-1 $\beta, 3 \beta, 5 \beta$-trihydroxy-1-O- $\beta$-D-xyloside (3) were obtained from the roots and rhizomes of $T$. chinensis together with the two known compounds tupisteroide B (4) and $5 \beta$-furost- $\Delta^{25(27)}$-en- $1 \beta, 2 \beta, 3 \beta, 4 \beta, 5 \beta, 7 \alpha, 22 \xi, 26$-octahydroxy-6-one-26-O- $\beta$-Dglucopyranoside (5) (Figure 1). The cytotoxic activity of 1-4 was evaluated on human A549 and H1299 tumor cells.
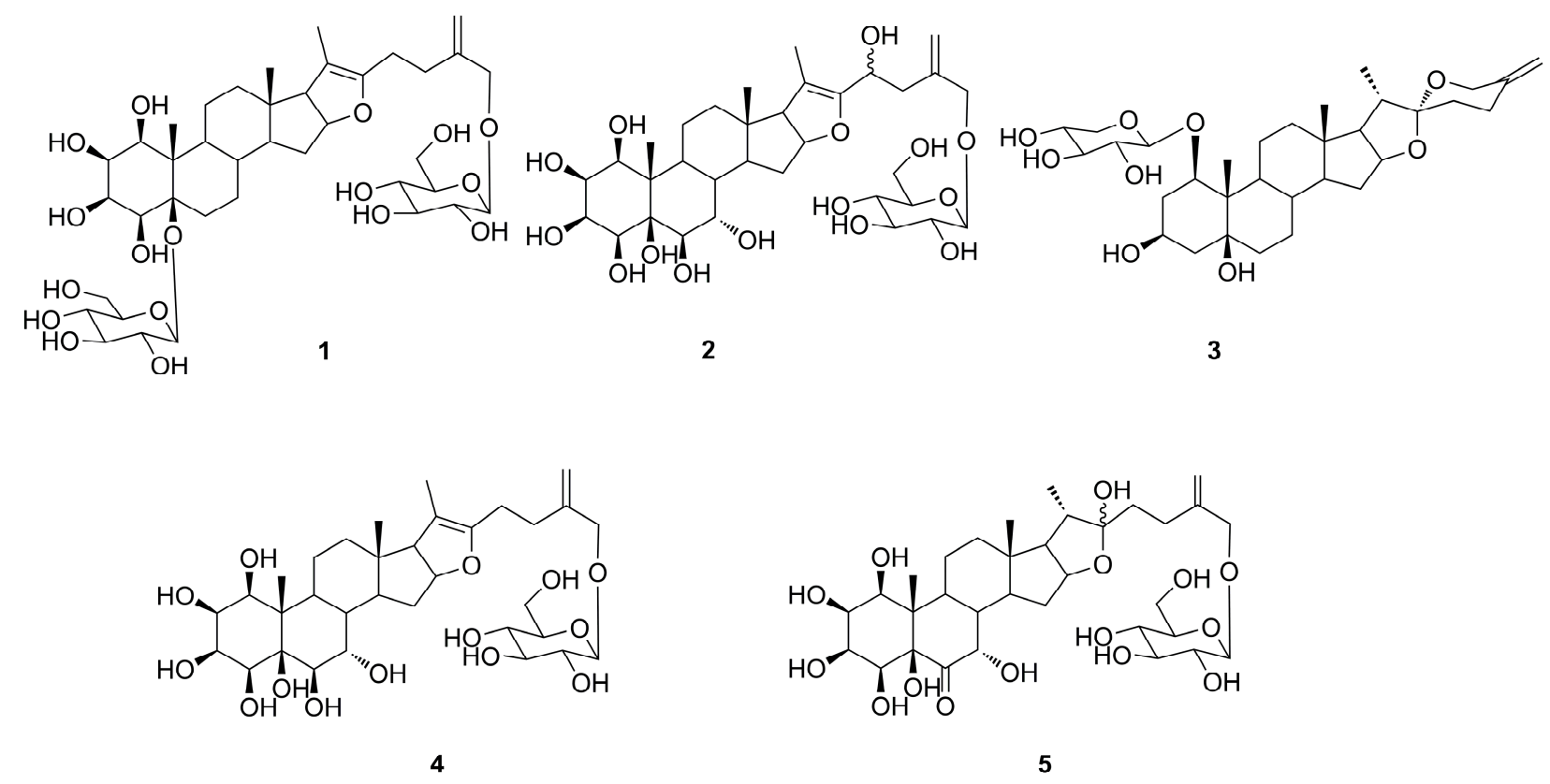

Figure 1. Structures of compounds 1-5.

\section{Results and Discussion}

Compound 1 was obtained as a white amorphous powder, which showed positive reactions in the Liebermann-Burchard, Ehrlich and Molisch reactions, suggesting that $\mathbf{1}$ was a furostanol glycoside. Its molecular formula was determined as $\mathrm{C}_{39} \mathrm{H}_{62} \mathrm{O}_{17}$ from the HR-ESI-MS peak at $m / z$ 801.3855 [M - H] $]^{-}$. 
The ${ }^{1} \mathrm{H}-\mathrm{NMR}$ spectrum showed three methyl protons at $\delta \mathrm{H} 0.67(3 \mathrm{H}, \mathrm{s}), 1.70(3 \mathrm{H}, \mathrm{s})$ and $1.58(3 \mathrm{H}, \mathrm{s})$, two exo-methylene protons $\left(\delta_{\mathrm{H}} 5.35(1 \mathrm{H}, \mathrm{brs})\right.$ and $\left.5.04(1 \mathrm{H}, \mathrm{brs})\right)$, as well as signals for two anomeric protons at $\left(\delta_{\mathrm{H}} 5.28(\mathrm{~d}, J=7.8 \mathrm{~Hz})\right.$ and $\left.4.89(1 \mathrm{H}, \mathrm{d}, J=7.7 \mathrm{~Hz})\right)$. The ${ }^{13} \mathrm{C}-\mathrm{NMR}$ spectrum displayed 39 carbon signals, 27 of which belonged to the aglycone carbons, while the remaining signals were assignable to two glucosyl moieties ( $\delta_{\mathrm{c}} 103.8,75.8,78.5,71.7,78.6$ and 62.6 , and $\delta_{\mathrm{C}} 97.4,76.2,78.6,71.9,78.8$ and 62.8). Among carbon signals of the aglycone, $\delta_{\mathrm{C}} 146.2$ and 111.6 were due to an olefinic bond group, $\delta_{\mathrm{C}} 14.3,13.7$ and 11.7 were due to three methyl groups, and $\delta_{\mathrm{C}} 77.8,68.1,75.2,67.6,87.4,84.4,64.5$ and 71.7 were due to eight oxygenated carbon groups, which indicated that $\mathbf{1}$ was a furostanol saponin with multiple hydroxyl groups. The structure of 1 was finally determined by analysis of its 2D NMR data (see Figure 2). The HMQC experiment allowed for the assignments of the proton and protonated carbon resonances in the NMR spectra of 1. HMQC correlations of $\left(\delta_{\mathrm{H}} 5.35(\mathrm{H}-27 \mathrm{a})\right.$ and $\left.5.04(\mathrm{H}-27 \mathrm{~b})\right)$ to $\delta_{\mathrm{C}} 111.6$, showed the appearance of a terminal olefinic bond at C-27. Then, HMBC correlations of H-27/C-24, C-25 and C-26, H-24/C-22, C-23, C-25 and C-26, H-26/C-24, C-25 and C-27, indicated that the appearance of an isopentene group, linked at $\mathrm{C}-22$ of the tetrahydrofuran ring of the furostanol saponin. Moreover, HMBC correlations of H-19/C-1, C-5, C-9 and C-10, H-3/C-1, C-2 and C-5, and H-6/C-4 and C-5, indicated that all hydroxyl groups were linked at $\mathrm{C}-1-\mathrm{C}-5$ of the $\mathrm{A}$ ring of the furostanol saponin (see Figure 2). Furthermore, the remaining HMBC correlations of H-18/C-12, C-13, C-14 and C-17, H-16/C-13, C-17, C-20 and C-22, H-21/C-17, C-20 and C-22, were assigned (see Figure 2). Therefore, the aglycone of 1 was identified as 1, 2, 3, 4, 5, 26-hexanol-furost-20 (22),25(27)-dien. In addition, the HMBC correlation signals of $\mathrm{H}-\mathrm{Glc}-1^{\prime} / \mathrm{C}-5$ and $\mathrm{H}-\mathrm{Glc}-1^{\prime \prime} / \mathrm{C}-26$, indicated that glucosyl groups were connected as (Glc-1"$O$-C-26) and (Glc-1'-O-C-5) (see Figure 2). The two glucosyl moieties were identified as D-glucose by acid hydrolysis of $\mathbf{1}$, followed by TLC comparison with a reference compound and optical rotation determination [12], and judged to be in a $\beta$-configuration [13] from the coupling constants of the anomeric protons $(7.8 \mathrm{~Hz}$ and $7.7 \mathrm{~Hz}$, respectively). In the NOESY spectrum of $\mathbf{1}$, the NOE correlations of Me-19/H-8, H-9/H-4, H-4/H-3 and H-2, and H-2/H-1 were observed (see Figure 2), indicated $\alpha$-axial configurations of H-1, H-2, H-3 and H-4, and $\beta$-orientation of Me-19, 1-OH, 2-OH, 3-OH, 4-OH and 5-OH, which supported the A/B cis ring junction pattern; the NOE correlations of Me-19/H-8, H-8/Me-18, and $\mathrm{H}-14 / \mathrm{H}-9, \mathrm{H}-16$ and $\mathrm{H}-17$, supported the $\mathrm{B} / \mathrm{C}$ and $\mathrm{C} / \mathrm{D}$ trans ring junction pattern; and the NOE correlations of Me-18/H-15b, H-15a/H-16 and H-17, and H-17/Me-21, suggested an $\alpha$-orientation of Me-21 (see Figure 2). Therefore, compound 1 was identified as $1 \beta, 2 \beta, 3 \beta, 4 \beta, 5 \beta, 26$-hexahydroxyfurost20(22),25(27)-dien-5,26-O- $\beta$-D-glucopyranoside.
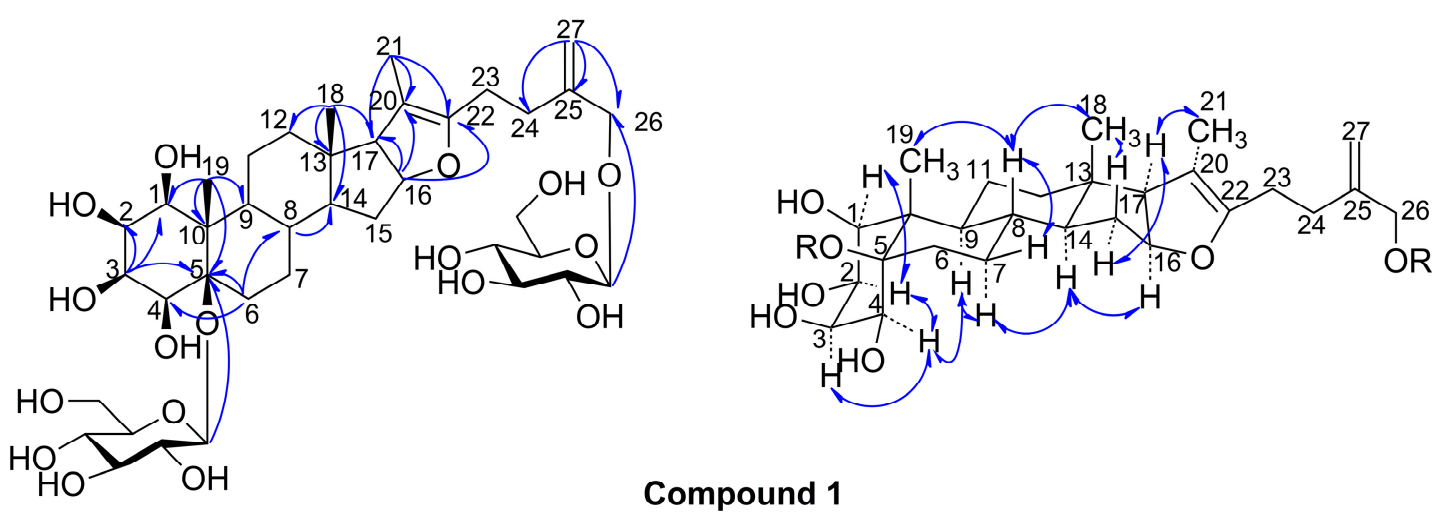

Compound 1

Figure 2. Key HMBC and NOESY correlations of the compound $\mathbf{1 .}$ 
Compound 2 was obtained as a white amorphous powder, which showed positive reactions in the Liebermann-Burchard, Ehrlich, and Molisch tests, suggesting that $\mathbf{2}$ was a furostanol glycoside. The molecular formula $\mathrm{C}_{33} \mathrm{H}_{52} \mathrm{O}_{15}$ was deduced from the HR-ESI-MS peak at $m / z 711.3198[\mathrm{M}+\mathrm{Na}]^{+}$. Comparison of the HR-ESI-MS and NMR data of $\mathbf{2}$ and $\mathbf{1}$, indicated almost similar NMR spectroscopic features, except for the number of oxygenated methine groups. In the ${ }^{13} \mathrm{C}-\mathrm{NMR}$ spectrum of $\mathbf{2}$, only one glucosyl moiety $\left(\delta_{\mathrm{C}} 104.2,75.6,80.0,72.1,79.0,63.2\right)$ was recognized, however, nine oxygenated carbon groups of the aglycone at $\delta_{\mathrm{C}} 79.1,67.7,76.1,70.2,78.6,74.0,72.5,64.8$ and 72.7 were identified. Meanwhile, the spectroscopic features of 2 were similar to those of tupisteroide B (4), indicating that seven hydroxyl groups were linked at $\mathrm{C}-1-\mathrm{C}-7$ of the furostanol saponin, which was confirmed by the ${ }^{1} \mathrm{H}-{ }^{1} \mathrm{H}$ COSY correlation of $\mathrm{H}-1 / \mathrm{H}-2 / \mathrm{H}-3 / \mathrm{H}-4$ and $\mathrm{H}-6 / \mathrm{H}-7$ and the HMBC correlation of H-19/C-1, C-5, C-9 and C-10, and H-6/C-4 and C-5 (see Figure 3). The 26-OH was connected with the glucosyl moiety from the correlation signals of $\mathrm{H}-\mathrm{Glc}-1^{\prime} / \mathrm{C}-26$ in the $\mathrm{HMBC}$ spectra (see Figure 3 ). The remaining hydroxyl group was deduced to be linked at $\mathrm{C}-23$, from one oxygen-bearing methine signal occurring at $\delta_{\mathrm{C}} 64.8$ in 2 , instead of a methylene carbon $(\mathrm{C}-23)$ at $\delta_{\mathrm{C}} 34.3$ in 4 , which was correlated with a proton signal at $\delta_{\mathrm{H}} 5.13(\mathrm{dd}, J=6.0,8.0 \mathrm{~Hz}, \mathrm{H}-23)$ in the HMQC spectrum, and the correlation signals of $\mathrm{H}-23 / \mathrm{H}-24$ in the ${ }^{1} \mathrm{H}-{ }^{1} \mathrm{H}$ COSY spectrum, the correlation signals of $\mathrm{H}-23 / \mathrm{C}-20, \mathrm{C}-22, \mathrm{C}-24$ and C-25, $\mathrm{H}-24 / \mathrm{C}-22, \mathrm{C}-23, \mathrm{C}-25, \mathrm{C}-26$ and C-27, and H-27/C-24, C-25 and C-26 in the HMBC spectrum (see Figure 3). In addition, the glucosyl moiety was identified as $\beta$-D-glucose by the acid hydrolysis procedure and the coupling constant analysis of the anomeric proton $(J=7.8 \mathrm{~Hz})$, according to the same protocol as that described for $\mathbf{1}$. Thus, the planar structure of $\mathbf{2}$ was deduced as 1,2,3,4,5,6,7,23,26-nonanolfurost20(22),25(27)-dien-26-O- $\beta$-D-glucose. In the NOESY spectrum of $\mathbf{2}$, the NOE correlations of Me-19/H-8, $\mathrm{H}-4 / \mathrm{H}-2, \mathrm{H}-3$ and $\mathrm{H}-9$, and $\mathrm{H}-2 / \mathrm{H}-1$ were observed, indicating $\alpha$-axial configurations of $\mathrm{H}-1, \mathrm{H}-2, \mathrm{H}-3$, and $\mathrm{H}-4$, and $\beta$-orientation of $\mathrm{Me}-19,1-\mathrm{OH}, 2-\mathrm{OH}, 3-\mathrm{OH}, 4-\mathrm{OH}$ and 5-OH, which supported the A/B cis ring junction pattern (see Figure 3). Besides, NOE correlation of $\mathrm{H}-7 / \mathrm{H}-8$ was observed and no correlation signals was occurred between Me-19/H-6, which indicated $\alpha$-axial configuration of $7-\mathrm{OH}$ and $\beta$-orientation of 6-OH (see Figure 3). Finally, the NOE correlations of H-8/Me-19 and Me-18, and H-14/H-16 and H-17, supported the $\mathrm{B} / \mathrm{C}$ and $\mathrm{C} / \mathrm{D}$ trans ring junction pattern; and the NOE correlations of $\mathrm{Me}-18 / \mathrm{H}-15 \mathrm{~b}$, $\mathrm{H}-15 \mathrm{a} / \mathrm{H}-16$ and H-17, and H-17/Me-21, suggested the $\alpha$-orientation of Me-21 (see Figure 3). Therefore, compound 2 was identified as $1 \beta, 2 \beta, 3 \beta, 4 \beta, 5 \beta, 6 \beta, 7 \alpha, 23 \xi, 26$-nonahydroxyfurost-20(22),25(27)-dien-26-O- $\beta$ D-glucopyranoside.
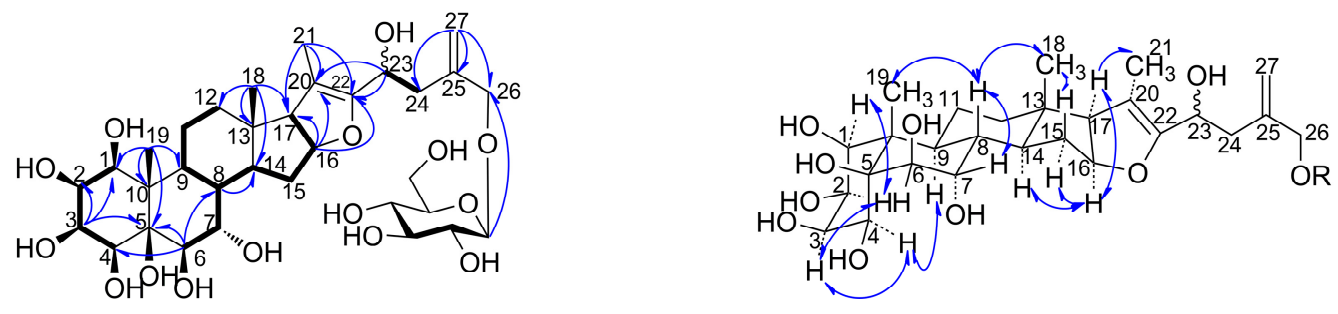

Compound 2

Figure 3. Key HMBC, ${ }^{1} \mathrm{H}-{ }^{1} \mathrm{H}$ COSY and NOESY correlations of the compound 2.

Compound 3 was obtained as a white amorphous powder, and the molecular formula of $\mathrm{C}_{32} \mathrm{H}_{50} \mathrm{O}_{9}$ was established by the HR-ESI-MS signal at $m / z 579.3590[\mathrm{M}+\mathrm{H}]^{+}$. The ${ }^{13} \mathrm{C}-\mathrm{NMR}$ spectrum exhibited 32 carbon signals, 27 of which were attributed to the aglycone carbons, while the remaining signals were 
assignable to a characteristic of a xylosyl moiety $\left(\delta_{\mathrm{C}} 104.1,75.8,78.9,71.5\right.$ and 68.1$)$, which was identified as $\beta$-D-xylose by the coupling constant analysis of the anomeric proton $(J=7.2 \mathrm{~Hz})$, the acid hydrolysis procedure, TLC comparison, and the optical rotation determination. Among the aglycone carbon signals, the quaternary carbon signal at $\delta_{\mathrm{c}} 109.9$ (see, Table 1), was identified as an acetal carbon (C-22), a characteristic signal of spirostanol or norspirostanol saponin [14]. In HMBC spectrum, the anomeric proton [4.81 $(1 \mathrm{H}, \mathrm{d}, J=7.2 \mathrm{~Hz})]$ of the xylose was correlated with $\delta_{\mathrm{C}} 82.5$, which was confirmed as $\mathrm{C}-1$ for the HMQC correlation of $\delta_{\mathrm{H}} 4.26(\mathrm{H}-1) / \delta_{\mathrm{C}} 82.5(\mathrm{C}-1),{ }^{1} \mathrm{H}-{ }^{1} \mathrm{H}$ COSY correlations of $\mathrm{H}-1 / \mathrm{H}-2 / \mathrm{H}-3 / \mathrm{H}-4$, and HMBC correlations of H-19/C-1, C-5, C-9 and C-10 (see, Figure 4). Moreover, HMBC correlations of H-18/C-12, C-13, C-14 and C-17, H-21/C-17, C-20 and C-22, H-23/C-22, and H-27/C-24, C-25 and C-26, were observed (see, Figure 4). The above data indicated the planar structure of $\mathbf{3}$ as spirost-25(27)-en1,3,5-trihydroxy-1-O- $\beta$-D-xyloside. In the NOESY spectrum of 3 (see, Figure 4), the NOE correlations of Me-19/H-8, H-3/H-2a and H-4, H-2a/H-1, and H-4a/H-7a and H-9, indicated $\alpha$-axial configurations of $\mathrm{H}-1$ and $\mathrm{H}-3$, and $\beta$-orientation of $\mathrm{Me}-19,1-\mathrm{OH}, 3-\mathrm{OH}$ and $5-\mathrm{OH}$, which supported the $\mathrm{A} / \mathrm{B}$ cis ring junction pattern; the NOE correlations of $\mathrm{H}-8 / \mathrm{Me}-19$ and Me-18, and $\mathrm{H}-14 / \mathrm{H}-9$ and $\mathrm{H}-7 \mathrm{a}$, supported the $\mathrm{B} / \mathrm{C}$ and $\mathrm{C} / \mathrm{D}$ trans ring junction pattern; the NOE correlations of Me-18/H-15b and H-20, H-15a/H-16 and $\mathrm{H}-17$, and $\mathrm{H}-17 / \mathrm{Me}-21$, suggested $\alpha$-orientation of Me-21. These spectra data was almost similar to those of $(20 S, 22 R)-1 \beta, 3 \beta, 5 \beta$-trihydroxyspirost-25(27)-en-5-O- $\beta$-D-glucopyranoside [8], expect for the site of glycosylation. Therefore, compound 3 was elucidated as $(20 S, 22 R)$-spirost-25(27)-en-1 $\beta, 3 \beta, 5 \beta-$ trihydroxy-1-O- $\beta$-D-xyloside.

Table 1. ${ }^{1} \mathrm{H}-\mathrm{NMR}$ and ${ }^{13} \mathrm{C}-\mathrm{NMR}$ spectral data of compounds $\mathbf{1}-\mathbf{3}$.

\begin{tabular}{|c|c|c|c|c|c|c|}
\hline \multirow{2}{*}{ Position } & \multicolumn{2}{|r|}{1} & \multicolumn{2}{|r|}{2} & \multicolumn{2}{|r|}{3} \\
\hline & $\delta c^{a}$ & $\delta_{\mathrm{H}}{ }^{\mathrm{a}}(J$ in $\mathrm{Hz})$ & $\delta c^{b}$ & $\delta_{H}{ }^{b}(J$ in $\mathrm{Hz})$ & $\delta c^{c}$ & $\delta_{H^{c}}{ }^{\prime}(J$ in $\mathrm{Hz})$ \\
\hline 1 & 77.8 & 4.25 (brs) & 79.1 & 4.29 (brs) & 82.5 & 4.26 (brs) \\
\hline 2 & 68.1 & 4.38 (brs) & 67.7 & 4.33 (brs) & 30.4 & $\begin{array}{l}2.53(\mathrm{H}-2 \mathrm{a}, c a .) \\
1.85(\mathrm{H}-2 \mathrm{~b}, c a .)\end{array}$ \\
\hline 3 & 75.2 & 4.70 (brs) & 76.1 & 4.77 (brs) & 67.8 & 4.59 (brs) \\
\hline 4 & 67.6 & 4.08 (brs) & 70.2 & 5.33 (brs) & 40.0 & $\begin{array}{l}2.40(\mathrm{H}-4 \mathrm{a}, c a .) \\
2.04(\mathrm{H}-4 \mathrm{~b}, c a .)\end{array}$ \\
\hline 5 & 87.4 & - & 78.6 & - & 74.7 & - \\
\hline 6 & 24.9 & $1.93(c a),. 2.80(c a)$. & 74.0 & 5.03 (brs) & 36.3 & $1.54(c a),. 1.90(c a)$. \\
\hline 7 & 28.5 & $1.1(c a),. 1.51(c a)$. & 72.5 & 4.49 (brs) & 29.2 & $\begin{array}{l}0.98(\mathrm{H}-7 \mathrm{a}, c a .) \\
1.51(\mathrm{H}-7 \mathrm{~b}, c a .)\end{array}$ \\
\hline 8 & 34.4 & $1.59(c a)$. & 34.8 & $2.62(c a)$. & 35.4 & $1.67(c a)$. \\
\hline 9 & 46.6 & $1.19(c a)$. & 37.8 & $2.05(c a)$. & 46.3 & $1.15(c a)$. \\
\hline 10 & 46.2 & - & 46.3 & - & 44.9 & - \\
\hline 11 & 21.9 & $1.41(c a),. 1.44(c a)$. & 21.9 & $1.61(c a),. 1.67(c a)$. & 22.3 & 1.14(ca.),1.38 (ca.) \\
\hline 12 & 39.7 & $1.62(\mathrm{~d}, 12.0), 1.15(c a)$. & 40.0 & $1.70(\mathrm{~d}, 12.0), 1.24(c a)$. & 40.5 & $1.73(\mathrm{~d}, 12.5), 1.13(c a)$. \\
\hline 13 & 43.3 & - & 43.8 & - & 41.2 & - \\
\hline 14 & 54.3 & $0.76(c a)$. & 48.9 & $1.96(c a)$. & 56.7 & $1.12(c a)$. \\
\hline 15 & 31.0 & $\begin{array}{l}2.48(\mathrm{H}-15 \mathrm{a}, c a .) \\
2.38(\mathrm{H}-15 \mathrm{~b}, c a .)\end{array}$ & 34.7 & $\begin{array}{l}2.58(\mathrm{H}-15 \mathrm{a}, c a .) \\
1.65(\mathrm{H}-15 \mathrm{~b}, c a .)\end{array}$ & 32.7 & $\begin{array}{l}2.07(\mathrm{H}-15 \mathrm{a}, c a .) \\
1.48(\mathrm{H}-15 \mathrm{~b}, c a .)\end{array}$ \\
\hline 16 & 84.4 & $4.77(\mathrm{q}, 7.5)$ & 85.1 & $4.87(c a)$. & 81.9 & $4.62(\mathrm{q}, 7.2)$ \\
\hline
\end{tabular}


Table 1. Cont.

\begin{tabular}{|c|c|c|c|c|c|c|}
\hline \multirow{2}{*}{ Position } & \multicolumn{3}{|c|}{1} & \multirow{2}{*}{$\frac{2}{\delta_{H}{ }^{b}(J \text { in } H z)}$} & \multicolumn{2}{|r|}{3} \\
\hline & $\delta c^{a}$ & $\delta_{H}{ }^{a}(J$ in $H z)$ & $\delta c^{b}$ & & $\delta c^{c}$ & $\delta_{H}{ }^{c}(J$ in $\mathrm{Hz})$ \\
\hline 17 & 64.5 & $2.42(c a)$. & 65.3 & 2.57 (ca.) & 63.5 & $1.88(c a)$. \\
\hline 18 & 14.3 & $0.67(\mathrm{~s})$ & 14.6 & $0.81(\mathrm{~s})$ & 17.0 & $0.87(\mathrm{~s})$ \\
\hline 19 & 13.7 & $1.70(\mathrm{~s})$ & 16.0 & $1.99(\mathrm{~s})$ & 14.4 & $1.59(\mathrm{~s})$ \\
\hline 20 & 103.9 & - & 105.9 & - & 42.4 & $2.00(c a)$. \\
\hline 21 & 11.7 & $1.58(\mathrm{~s})$ & 12.1 & $1.74(\mathrm{~s})$ & 15.5 & $1.10(\mathrm{~d}, 8.0)$ \\
\hline 22 & 151.8 & - & 154.2 & - & 109.9 & - \\
\hline 23 & 34.3 & 1.45 (ca.), 2.04 (ca.) & 64.8 & $5.13(\mathrm{dd}, 6.0,8.0)$ & 33.7 & $1.81(c a)$. \\
\hline 24 & 24.6 & 2.37 (ca.), 2.47 (ca.) & 40.3 & $\begin{array}{l}2.88(\mathrm{H}-24 \mathrm{a}, \mathrm{dd}, 6.0,14.3) \\
3.10(\mathrm{H}-24 \mathrm{~b}, \mathrm{dd}, 8.0,14.3)\end{array}$ & 29.4 & $\begin{array}{l}2.26(c a .) \\
2.74(c a .)\end{array}$ \\
\hline 25 & 146.2 & - & 144.4 & - & 144.9 & - \\
\hline 26 & 71.7 & $\begin{array}{l}4.58(\mathrm{~d}, 13.0) \\
4.34(\mathrm{~d}, 13.0)\end{array}$ & 72.7 & $\begin{array}{l}4.75(\mathrm{~d}, 13.0) \\
4.61(\mathrm{~d}, 13.0)\end{array}$ & 65.5 & $\begin{array}{l}4.50(\mathrm{~d}, 12.1) \\
4.07(\mathrm{~d}, 12.1)\end{array}$ \\
\hline 27 & 111.6 & $\begin{array}{l}5.35(\mathrm{H}-27 \mathrm{a}, \mathrm{s}) \\
5.04(\mathrm{H}-27 \mathrm{~b}, \mathrm{~s})\end{array}$ & 114.6 & $\begin{array}{l}5.47(\mathrm{H}-27 \mathrm{a}, \mathrm{s}) \\
5.28(\mathrm{H}-27 \mathrm{~b}, \mathrm{~s})\end{array}$ & 109.2 & $\begin{array}{l}4.81(\mathrm{H}-27 \mathrm{a}, \mathrm{s}) \\
4.84(\mathrm{H}-27 \mathrm{~b}, \mathrm{~s})\end{array}$ \\
\hline $1^{\prime}$ & 97.4 & $5.28(\mathrm{~d}, 7.8)$ & 104.2 & $5.0(\mathrm{~d}, 7.8)$ & 104.1 & $4.81(\mathrm{~d}, 7.2)$ \\
\hline $2^{\prime}$ & 76.2 & 3.95 (ca.) & 75.6 & 4.12 (ca.) & 75.8 & 3.99 (ca.) \\
\hline $3^{\prime}$ & 78.6 & $4.01(c a)$. & 80.0 & $4.36(c a)$. & 78.9 & $4.21(c a)$. \\
\hline $4^{\prime}$ & 71.9 & $4.02(c a)$. & 72.1 & 4.27 (ca.) & 71.5 & $4.23(c a)$. \\
\hline $5^{\prime}$ & 78.8 & 4.22 (ca.) & 79.0 & $3.96(c a)$. & 68.1 & $\begin{array}{c}3.78(\mathrm{t}, 10.5), \\
4.42(\mathrm{dd}, 4.5,11.5)\end{array}$ \\
\hline $6^{\prime}$ & 62.8 & $4.52(c a),$.4.21 (ca.) & 63.2 & $\begin{array}{l}4.58(\mathrm{dd}, 2.0,11.8), \\
4.41(\mathrm{dd}, 5.5,11.8)\end{array}$ & - & - \\
\hline $1^{\prime \prime}$ & 103.8 & $4.89(\mathrm{~d}, 7.7)$ & - & - & - & - \\
\hline $2^{\prime \prime}$ & 75.8 & $4.03(c a)$. & - & - & - & - \\
\hline $3 "$ & 78.5 & $4.22(c a)$. & - & - & - & - \\
\hline $4^{\prime \prime}$ & 71.7 & $4.19(c a)$. & - & - & - & - \\
\hline $5^{\prime \prime}$ & 78.6 & 3.92 (ca.) & - & - & - & - \\
\hline $6^{\prime \prime}$ & 62.6 & 4.52 (ca.), 4.35 (ca.) & - & - & - & - \\
\hline
\end{tabular}

${ }^{\mathrm{a}} \delta$ in pyridine- $d_{5}$, in ppm from TMS; coupling constants $(J)$ in $\mathrm{Hz} ;{ }^{1} \mathrm{H}-\mathrm{NMR}$ at $500 \mathrm{MHz}$ and ${ }^{13} \mathrm{C}-\mathrm{NMR}$ at $125 \mathrm{MHz}$; ${ }^{\mathrm{b}} \delta$ in pyridine- $d_{5},{ }^{1} \mathrm{H}-\mathrm{NMR}$ at $600 \mathrm{MHz}$ and ${ }^{13} \mathrm{C}-\mathrm{NMR}$ at $150 \mathrm{MHz} ;{ }^{\mathrm{c}} \delta$ in pyridine- $d_{5},{ }^{1} \mathrm{H}-\mathrm{NMR}$ at $400 \mathrm{MHz}$ and ${ }^{13} \mathrm{C}-\mathrm{NMR}$ at $100 \mathrm{MHz}$.

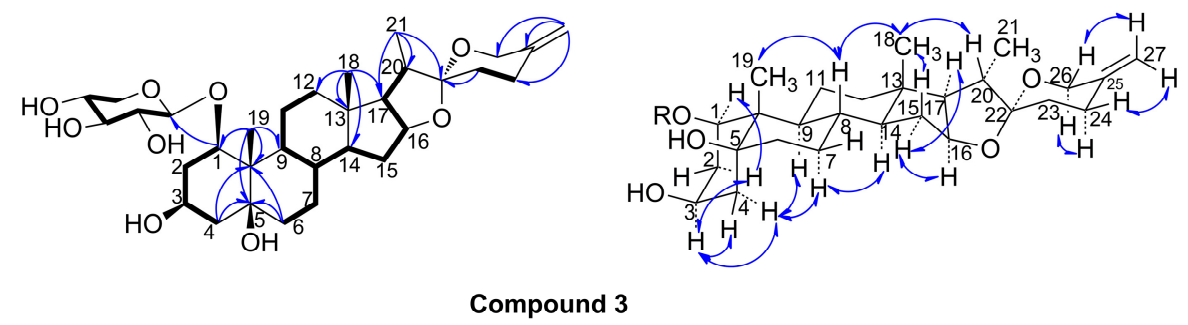

Figure 4. Key HMBC, ${ }^{1} \mathrm{H}-{ }^{1} \mathrm{H}$ COSY and NOESY correlations of the compound 3.

Additionally, the known furostanol saponins were identified by comparison of their spectroscopic data with those reported in the literature as tupisteroide $B(4)[15]$ and $5 \beta$-furost- $\Delta^{25(27)}$-en$1 \beta, 2 \beta, 3 \beta, 4 \beta, 5 \beta, 7 \alpha, 22 \xi, 26$-octaol-6-one-26-O- $\beta$-D-glucopyranoside (5) [16]. 
The cytotoxic activity of 1-4 towards the A549 and H1299 tumor cell lines was measured by the MTT method. Compound 3 exhibited cytotoxicity against A549 cells ( $\left.\mathrm{IC}_{50} 86.63 \pm 2.33 \mu \mathrm{mol} \cdot \mathrm{L}^{-1}\right)$ and H1299 cells (IC50 $88.21 \pm 1.34 \mu \mathrm{mol} \cdot \mathrm{L}^{-1}$, see Tables 2 and 3). Considering 3 is a spirostanol saponin, our results showed the cytotoxic activity of this type of steroidal saponin as mentioned in the literature [8,17-19].

Table 2. Activities of compounds $\mathbf{1}-\mathbf{4}$ on proliferation of the H1299 cells.

\begin{tabular}{ccccccc}
\hline Comp. & $\mathbf{1} \boldsymbol{\mu M}$ & $\mathbf{3} \boldsymbol{\mu M}$ & $\mathbf{1 0} \boldsymbol{\mu M}$ & $\mathbf{3 0} \boldsymbol{\mu M}$ & $\mathbf{1 0 0} \boldsymbol{\mu M}$ & $\mathbf{I} \mathbf{C}_{\mathbf{5 0} \boldsymbol{\mu} \mathbf{M}}$ \\
\hline 1 & $1.93 \pm 0.95^{* *}$ & $13.50 \pm 1.81^{* *}$ & $14.69 \pm 1.41^{* *}$ & $16.53 \pm 1.26^{* *}$ & $16.90 \pm 0.69^{* *}$ & $>100$ \\
2 & $3.95 \pm 2.09^{* *}$ & $5.75 \pm 1.48^{* *}$ & $11.50 \pm 3.22^{* *}$ & $16.17 \pm 1.50^{* *}$ & $20.04 \pm 1.36^{* *}$ & $>100$ \\
3 & $4.55 \pm 1.10^{* *}$ & $8.04 \pm 1.94 * *$ & $13.47 \pm 0.61 * *$ & $17.39 \pm 0.73^{* *}$ & $55.74 \pm 0.87 * *$ & $88.21 \pm 1.34$ \\
4 & $4.01 \pm 0.86^{* *}$ & $9.26 \pm 0.44 * *$ & $11.46 \pm 2.91^{* *}$ & $13.47 \pm 1.49^{* *}$ & $26.07 \pm 0.99 * *$ & $>100$ \\
$5-\mathrm{FU}$ & $3.07 \pm 0.52$ & $5.21 \pm 0.28$ & $17.39 \pm 1.11$ & $47.88 \pm 1.38$ & $71.96 \pm 2.49$ & $38.65 \pm 1.59$ \\
\hline
\end{tabular}

The data are expressed as mean $\pm \mathrm{SD}$ of three independent experiments $(* * p<0.01 v s$. control).

Table 3. Activities of compounds 1-4 on proliferation of the A549 cells.

\begin{tabular}{cccccccc}
\hline Comp. & $\mathbf{1} \boldsymbol{\mu M}$ & $\mathbf{3} \boldsymbol{\mu M}$ & $\mathbf{1 0} \boldsymbol{\mu M}$ & $\mathbf{3 0} \boldsymbol{\mu M}$ & $\mathbf{1 0 0} \boldsymbol{\mu M}$ & $\mathbf{I C} \mathbf{m} \boldsymbol{\mu M}$ \\
\hline 1 & $3.75 \pm 1.24 * *$ & $11.62 \pm 1.88^{* *}$ & $12.83 \pm 2.02 * *$ & $14.35 \pm 0.77 * *$ & $20.19 \pm 3.63 * *$ & $>100$ \\
2 & $4.17 \pm 1.30 * *$ & $7.68 \pm 1.27 * *$ & $11.07 \pm 1.57 * *$ & $13.80 \pm 2.05 * *$ & $23.11 \pm 0.74 * *$ & $>100$ \\
3 & $3.95 \pm 0.95 * *$ & $7.90 \pm 1.67 * *$ & $13.05 \pm 1.75 * *$ & $20.60 \pm 2.40 * *$ & $56.17 \pm 1.98 * *$ & $86.63 \pm 2.33$ \\
4 & $2.93 \pm 1.18 * *$ & $6.65 \pm 0.94 * *$ & $7.01 \pm 2.47 * *$ & $13.21 \pm 1.40 * *$ & $24.75 \pm 1.62 * *$ & $>100$ \\
$5-\mathrm{FU}$ & $6.97 \pm 0.82$ & $9.03 \pm 1.21$ & $23.76 \pm 1.22$ & $42.18 \pm 1.22$ & $69.24 \pm 2.05$ & $42.78 \pm 1.63$ \\
\hline
\end{tabular}

The data are expressed as mean $\pm \mathrm{SD}$ of three independent experiments (** $p<0.01 v s$. control).

\section{Experimental Section}

\subsection{General Information}

The IR spectra were recorded on a TENSOR-27 instrument (Bruker, Rheinstetten, Germany). ESI-MS was performed on a Quattro Premier instrument (Waters, Milford, MA, USA). The HR-ESI-MS spectra were recorded on an Agilent Technologies 6550 Q-TOF (Santa Clara, CA, USA). 1D and 2D NMR spectra were recorded on Bruker-AVANCE 400, Bruker-AVANCE 500 and Bruker-AVANCE 600 instrument (Bruker, Rheinstetten, Germany) with TMS as an internal standard. The analytical HPLC was performed on a Waters 2695 Separations Module coupled with a 2996 Photodiode Array Detector and a Accurasil C18 column ( $4.6 \mathrm{~mm} \times 250 \mathrm{~mm}, 5 \mathrm{~mm}$ particles, Ameritech, Chicago, IL, USA). Semipreparative HPLC was performed on a system comprising an LC-6AD pump (Shimadzu, Kyoto, Japan) equipped with a SPD-20A UV detector and a Ultimate XB-C18 (10 mm $\times 250 \mathrm{~mm}, 5 \mathrm{~mm}$ particles $)$ or YMC-Pack-ODSA (10 mm $\times 250 \mathrm{~mm}, 5 \mathrm{~mm}$ particles). D101 was from Sunresin New Materials Co. Ltd. (Xi'an, China). Silica gel was purchased from Qingdao Haiyang Chemical Group Corporation (Qingdao, China).

\subsection{Plant Material}

The roots and rhizomes of $T$. chinensis Baker were collected from the Taibai region of Qinba Mountains in Shaanxi Province, China, in August 2010, and identified by senior experimentalist Jitao 
Wang. A voucher specimen (herbarium No. 20100816) has been deposited in the Medicinal Plants Herbarium (MPH), Shaanxi University of Chinese Medicine, Xianyang, China.

\subsection{Extraction and Isolation}

The air-dried and powdered underground parts of T. chinensis $(1.5 \mathrm{~kg})$ were extracted with $65 \% \mathrm{EtOH}$ $(15 \mathrm{~L})$ three times at $80{ }^{\circ} \mathrm{C}$. The combined $\mathrm{EtOH}$ extracts were evaporated to $6 \mathrm{~L}$, and applied to a resin D101 column, eluting with $\mathrm{H}_{2} \mathrm{O}, 20 \% \mathrm{EtOH}, 60 \% \mathrm{EtOH}$, and 95\% EtOH to give four fractions (Fr.1-Fr.4). Fr.3 (75 g) was subjected to column chromatography (CC) on silica gel, eluting with gradient solvent system $\left(\mathrm{CHCl}_{3}-\mathrm{MeOH}-\mathrm{H}_{2} \mathrm{O}, 100: 0: 0-0: 50: 50\right)$ to yield nine fractions (Fr.3-1-Fr.3-9). Fr.3-6 (5 g) was separated over silica gel using $\mathrm{CHCl}_{3}-\mathrm{MeOH}(100: 1-50: 50)$ as eluent to obtain eight fractions (Fr.3-6-1-Fr.3-6-8). Fr.3-6-5 (150 mg) and Fr.3-6-7 (370 mg) were purified by HPLC (YMC-Pack-ODS-A, $10 \mathrm{~mm} \times 250 \mathrm{~mm}, 5 \mu \mathrm{m}$ particles, flow rate: $1.0 \mathrm{~mL} \cdot \mathrm{min}^{-1}$ ) with $\mathrm{CH}_{3} \mathrm{OH}-\mathrm{H}_{2} \mathrm{O}$ $(45: 55)$ as mobile phase to afford $\mathbf{1}\left(23 \mathrm{mg} ; t_{R}=35 \mathrm{~min}\right), \mathbf{2}\left(15 \mathrm{mg} ; t_{R}=27 \mathrm{~min}\right), \mathbf{3}\left(20 \mathrm{mg} ; t_{R}=43 \mathrm{~min}\right)$, $4\left(27 \mathrm{mg} ; t_{R}=47 \mathrm{~min}\right)$ and $5\left(1.8 \mathrm{mg} ; t_{R}=65 \mathrm{~min}\right)$.

\section{4. $1 \beta, 2 \beta, 3 \beta, 4 \beta, 5 \beta, 26-H e x a h y d r o x y f u r o s t-20(22), 25(27)$-dien-5,26-O- $\beta$-D-glucopyranoside (1)}

A white amorphous powder, IR (KBr) vmax: 3450, 2980, 1694, 1025, 907, 804, $772 \mathrm{~cm}^{-1} .{ }^{1} \mathrm{H}-\mathrm{NMR}$ (500 MHz, pyridine- $d 5$ ) and ${ }^{13} \mathrm{C}-\mathrm{NMR}\left(125 \mathrm{MHz}\right.$, pyridine- $\left.d_{5}\right)$ spectral data, see Table $1 ; \mathrm{m} / z$ 801.3855 $[\mathrm{M}-\mathrm{H}]^{-}$(calcd. for $\left.\mathrm{C}_{39} \mathrm{H}_{61} \mathrm{O}_{17}, 801.3909\right)$.

\section{5. $1 \beta, 2 \beta, 3 \beta, 4 \beta, 5 \beta, 6 \beta, 7 \alpha, 23 \xi, 26-N o n a h y d r o x y f u r o s t-20(22), 25(27)$-dien-26-O- $\beta$-D-glucopyranoside (2)}

A white amorphous powder, IR (KBr) vmax: 3475, 2980, 1742, 1062, 904, $804 \mathrm{~cm}^{-1}$. ${ }^{1} \mathrm{H}-\mathrm{NMR}(600 \mathrm{MHz}$, pyridine- $\left.d_{5}\right)$ and ${ }^{13} \mathrm{C}-\mathrm{NMR}\left(150 \mathrm{MHz}\right.$, pyridine- $\left.d_{5}\right)$ spectral data, see Table $1 ; m / z 711.3198[\mathrm{M}+\mathrm{Na}]^{+}$ (calcd. for $\mathrm{C}_{33} \mathrm{H}_{52} \mathrm{O}_{15} \mathrm{Na}, 711.3204$ ).

\section{6. (20S,22R)-Spirost-25(27)-en-1 $\beta, 3 \beta, 5 \beta$-trihydroxy-1-O- $\beta$-D-xyloside (3)}

A white amorphous powder; IR (KBr) vmax: 3306, 2922, 1650, 1042, 989, 917, 892, $876 \mathrm{~cm}^{-1}$; ${ }^{1} \mathrm{H}-\mathrm{NMR}$ (400 MHz, pyridine- $d 5$ ) and ${ }^{13} \mathrm{C}-\mathrm{NMR}(100 \mathrm{MHz}$, pyridine- $d 5$ ) spectral data, see Table $1 ; \mathrm{m} / z$ $579.3590[\mathrm{M}+\mathrm{H}]^{+}$(calcd. for $\mathrm{C}_{32} \mathrm{H}_{51} \mathrm{O} 9,579.3633$ ).

\subsection{Acid Hydrolysis of Compounds 1, 2, 3 and Absolute Sugar Configuration Determination}

The solutions of compounds $1(3 \mathrm{mg}), \mathbf{2}(3 \mathrm{mg})$ and $\mathbf{3}(5 \mathrm{mg})$ were hydrolyzed with $2 \mathrm{~N} \mathrm{HCl}(5 \mathrm{~mL})$ for $5 \mathrm{~h}$ at $80^{\circ} \mathrm{C}$, respectively. The reaction mixtures were concentrated and dried by $\mathrm{N}_{2}$, and then water $(5 \mathrm{~mL})$ was added and the mixtures were extracted with EtOAc $(3 \times 5 \mathrm{~mL})$. The aqueous layers of 1 and 2 were subjected to $\mathrm{CC}$ over silica gel eluted with $\mathrm{MeCN}-\mathrm{H}_{2} \mathrm{O}(8: 1)$ to yield D-glucose, which was determined by TLC comparison $\left(\mathrm{MeCN}-\mathrm{H}_{2} \mathrm{O}, 6: 1\right)$ with the authentic sugar and the optical rotation determination $[\alpha]_{\mathrm{D}}^{20}+49.2\left(c 0.16, \mathrm{H}_{2} \mathrm{O}\right)$. The aqueous layer of 3 was subjected to $\mathrm{CC}$ over silica gel eluted with $\mathrm{MeCN}-\mathrm{H}_{2} \mathrm{O}(8: 1-15: 1)$ to yield D-xylose, which was identified by TLC comparison with the authentic sugar and the optical rotation determination $[\alpha]_{\mathrm{D}}^{20}+17.9\left(c 0.14, \mathrm{H}_{2} \mathrm{O}\right)$. 


\subsection{Cytotoxicity Assay}

The cytotoxic activity assays towards the A549 and H1299 tumor cell lines were measured by the MTT method in vitro, using 5-fluorouracil as positive control. Briefly, $1 \times 10^{4} \mathrm{~mL}^{-1}$ cells were seeded into 96-well plates and allowed to adhere for $24 \mathrm{~h}$. Compounds 1-4 were dissolved in DMSO and diluted with complete medium to five concentration levels (from $0.001 \mathrm{mmol} \cdot \mathrm{L}^{-1}$ to $0.1 \mathrm{mmol} \cdot \mathrm{L}^{-1}$ ) for inhibition rate determination. After incubation at $37^{\circ} \mathrm{C}$ for $4 \mathrm{~h}$, the supernatant was removed before adding DMSO $(100 \mu \mathrm{L})$ to each well. 5-Fluorouracil $(5-\mathrm{Fu})$ was used as positive control. The inhibition rate (IR) and IC50 were calculated. Values are mean $\pm \mathrm{SD}, n=3$, ** $p<0.01$ vs. DMEM control. Compound 3 exhibited cytotoxicity against A549 cells ( $\mathrm{IC}_{50} 86.63 \pm 2.33 \mu \mathrm{mol} \cdot \mathrm{L}^{-1}$ ) and $\mathrm{H} 1299$ cells $\left(\mathrm{IC}_{50} 88.21 \pm 1.34 \mu \mathrm{mol} \cdot \mathrm{L}^{-1}\right.$ ), while the positive control of 5-Fu exhibited cytotoxicity against A549 cells (IC50 $42.78 \pm 1.63 \mu \mathrm{mol} \cdot \mathrm{L}^{-1}$ ) and H1299 cells (IC50 $38.65 \pm 1.59 \mu \mathrm{mol} \cdot \mathrm{L}^{-1}$ ), respectively, (see Tables 2 and 3 ).

\section{Supplementary Materials}

IR, HR-ESI-MS, ${ }^{1} \mathrm{H}-\mathrm{NMR}{ }^{13} \mathrm{C}-\mathrm{NMR}$ and $2 \mathrm{D}$ NMR spectra for compounds $\mathbf{1}-\mathbf{3}$ can be accessed at: http://www.mdpi.com/1420-3049/20/08/13659/s1.

\section{Acknowledgments}

This project was financially supported by the National Natural Science Foundations of China (grant No. 81102805, 81373978), the Open Projects Program of the Key Laboratory of Tibetan Medicine Research, Chinese Academy of Sciences (grant No. 2014-TMR-01), the Innovative Research Team in TCM Material Foundation and Key Preparation Technology (grant No. 2012KCT-20), the Innovation Projects of Science and Technology in Shaanxi Province (grant No. 2011KTCQ03-02, 2013KTCQ03-14), and the Key Program of Shaanxi University of Chinese Medicine (grant No. 2015PY09).

\section{Author Contributions}

Every author has participated in the research and did his or her individual contribution to the article: Y.L. and X.W. conducted the experiments and collected the data; D.Z. and Y.J. planned and coordinated the experiments; H.H. and F.W. carried out the cytotoxicity biology experiments; X.Y. and Z.T. analysed the data; X.S. designed the study, and Z.Y. planned and oversaw the research project and drafted the paper. Finally, All authors read and approved the final manuscript.

\section{Conflicts of Interest}

The authors declare no conflict of interest.

\section{References}

1. Song, X.; Liu, H. Research and Application of "Qi-Medicines" in Taibai Mountains; People's Medical Publishing House: Beijing, China, 2011. 
2. Wu, X.; Fan, J.; Ouyang, Z.; Ning, R.; Guo, W.; Shen, Y.; Sun, Y.; Xu, Q. Tupistra chinensis extract attenuates murine fulminant hepatitis with multiple targets against activated $\mathrm{T}$ lymphocytes. J. Pharm. Pharmacol. 2014, 66, 453-465.

3. Pan, Z.; Li, Y.; Liu, J.; Ning, D.; Li, D.; Wu, X.; Wen, Y. A cytotoxic cardenolide and a saponin from the rhizomes of Tupistra chinensis. Fitoterapia 2012, 83, 1489-1493.

4. Cai, J.; Zhu, Z.; Yu, C.; Lei, L.; Wu, S. Saponin from Tupistra chinensis Baker inhibits mouse sarcoma S-180 cell proliferation in vitro and implanted solid tumor growth in mice. J. South. Med. Univ. 2007, 27, 188-190.

5. Li, Q.; Zou, K.; Wang, Y. Experimental study on vitro anti-tumor action of "Kai-Kou-Jian" extract. Chin. J. Ethnomed. Ethnopharm. 2007, 86, 164-167.

6. Liu, C.; Guo, Z.; Xue, Y.; Cheng, J.; Huang, N.; Zhou, Y.; Cheng, F.; Zou, K. Five new furostanol saponins from the rhizomes of Tupistra chinensis. Fitoterapia 2012, 83, 323-328.

7. Huang, W.; Zhang, H.; Zou, K.; Chen, J.; Li, X.; Liu, C.; Huang, N. Total saponins of Tupistra chinensis induces apoptosis in A549 cells. Neoplasma 2012, 59, 613-621.

8. Song, X.; Li, Y.; Zhang, D.; Jiang, Y.; Wang, W.; Song, B.; Tang, Z.; Cui, J.; Yue, Z. Two new spirostanol saponins from the the roots and rhizomes of Tupistra chinensis. Phytochem. Lett. 2015, 13, 6-10.

9. Chai, J.; Song, X.; Wang, X.; Mei, Q.; Li, Z.; Cui, J.; Tang, Z.; Yue, Z. Two new compounds from the roots and rhizomes of Trillium tschonoskii. Phytochem. Lett. 2014, 10, 113-117.

10. Li, H.; Pan, X.; Mei, Q.; Song, X.; Pei, Y.; Yue, Z. Isolation and identification of chemical constituents from root and rhizoma of Trillium tschonoskii Maxim. J. Shenyang Pharm. Univ. 2013, 30, 509-516.

11. Yue, Z.; Qin, H.; Li, Y.; Sun, Y.; Wang, Z.; Yang, T.; Liu, L.; Wang, M.; Feng, F.; Mei, Q. Chemical constituents of the root of Jasminum giraldii. Molecules 2013, 18, 4766-4775.

12. Hudson, C.; Dale, J. Studies on the forms of D-glucose and their mutarotation. J. Am. Chem. Soc. 1917, 39, 320-328.

13. Zhang, X.; Chen, C.; Yang, J.; Ni, W.; Liu, H. New minor spirostane glycosides from Ypsilandra thibetica. Helv. Chim. Acta 2012, 95, 1087-1093.

14. Yan, W.; Ohtani, K.; Kasai, R.; Yamasaki, K. Steroidal saponins from fruits of Tribulus terrestris. Phytochemistry 1996, 42, 1417-1422.

15. Liu, C.; Guo, Z.; Xue, Y.; Zhang, H.; Zhang, H.; Zou, K.; Huang, N. Tupisteroide A-C, three new polyhydroxylated steroidal constituents from the roots of Tupistra chinensis. Magn. Reson. Chem. 2012, 50, 320-324.

16. Xu, L.; Zou, K.; Wang, J.; Wu, J.; Zhou, Y.; Dan, F.; Yang, J. New polyhydroxylated furostanol saponins with inhibitory action against NO production from Tupistra chinensis Rhizomes. Molecules 2007, 12, 2029-2037.

17. Li, Y.; Fan, L.; Sun, Y.; Miao, X.; Zhang, F.; Meng, J.; Han, J.; Zhang, D.; Zhang, R.; Yue, Z.; et al. Paris saponin VII from trillium tschonoskii reverses multidrug resistance of adriamycin-resistant MCF-7/ADR cells via P-glycoprotein inhibition and apoptosis augmentation. J. Ethnopharmcol. 2014, 154, 728-734. 
18. Li, Y.; Sun, Y.; Fan, L.; Zhang, F.; Meng, J.; Han, J.; Guo, X.; Zhang, D.; Zhang, R.; Yue, Z.; et al. Paris saponin VII inhibits growth of colorectal cancer cells through Ras signaling pathway. Biochem. Pharmacol. 2014, 88, 150-157.

19. Pan, W.; Chang, F.; Wei, L.; Wu, Y. New flavans, spirostanol sapogenins, and a pregnane genin from Tupistra chinensis and their cytotoxicity. J. Nat. Prod. 2003, 66, 161-168.

Sample Availability: Samples of the compounds 3-5 are available from the authors.

(C) 2015 by the authors; licensee MDPI, Basel, Switzerland. This article is an open access article distributed under the terms and conditions of the Creative Commons Attribution license (http://creativecommons.org/licenses/by/4.0/). 